\title{
The adenovirus early region 4 open reading frame $6 / 7$ protein regulates the DNA binding activity of the cellular transcription factor, E2F, through a direct complex
}

\author{
Min-Mei Huang and Patrick Hearing ${ }^{1}$ \\ Department of Microbiology, Health Sciences Center, State University of New York at Stony Brook, Stony Brook, New York \\ 11794 USA
}

\begin{abstract}
Nuclear factor E2F is a cellular protein that binds to the adenovirus E2 promoter and E1A enhancer regions and to the cellular c-myc P2 promoter region. The DNA binding activity of E2F, detected in vitro using nuclear extracts prepared from HeLa cells, is increased by adenovirus infection (termed E2F induction). We demonstrate here that a 19.5-kD protein, encoded by adenovirus early region 4 (E4) open reading frame (ORF) 6/7, is primarily responsible for the induction of E2F DNA binding activity to the E2 promoter region. Viral mutants that contain frame-shift mutations in E4 ORF 6/7 failed to induce E2F binding activity; a virus that carries an E4 ORF 6/7 cDNA in place of the E4-coding sequences induced E2F efficiently. Using gel mobility shift assays, we demonstrate that the E4 ORF 6/7 product induces the binding of E2F to the E2 promoter via a direct complex. The addition of a peptide-specific antiserum, directed against the E4 ORF 6/7 protein, to an in vitro E2F-binding reaction resulted in the formation of a DNA-protein complex with reduced gel mobility compared to the normal, adenovirus-induced E2F-E2 promoter complex. The formation of the E2F-E2 promoter-antibody complex was blocked by the addition of the cognate peptide used to generate the antiserum but not by a nonspecific peptide. Nuclear extracts prepared from adenovirus-infected HeLa cells were cleared of E2F binding activity using the ORF 6/7 peptide-specific serum, but not the preimmune serum, suggesting that E2F and the E4 ORF 6/7 product form a protein-protein complex in solution. The adenovirus E1A proteins are not absolutely required for the induction of E2F binding activity because the infection of HeLa cells with an E1A mutant, d1312, at high multiplicity resulted in E2F induction. Under these conditions of infection, the E4 ORF 6/7 product was synthesized. E2F binding activity was induced, but inefficiently, in cells infected with E4 ORF 6/7 mutants, indicating that an additional pathway may lead to E2F induction.
\end{abstract}

[Key Words: E4 ORF; E2F; DNA binding activity]

Received August 9, 1989; revised version accepted September 15, 1989.

Nuclear factor E2F is a cellular protein that binds to the adenovirus early region 2 (E2) promoter and E1A enhancer regions and to the cellular c-myc P2 promoter region (Kovesdi et al. 1986a,b, 1987; Hardy et al. 1989; Hiebert et al. 1989; Thalmeier et al. 1989). The E2Fbinding sites in the adenovirus E2 and c-myc P2 promoter regions are important elements for both basal and E1A-stimulated expression in vivo (Imperiale and Nevins 1984; Imperiale et al. 1985; Murthy et al. 1985; Zajchowski et al. 1985; Jalinot and Kedinger 1986; Hiebert et al. 1989; Loeken and Brady 1989; Thalmeier et al. 1989|. E2F DNA binding activity, detected in vitro using HeLa cell nuclear extracts, is increased by adenovirus

'Corresponding author. infection (Kovesdi et al. 1986a,b, 1987; SivaRaman and Thimmappaya 1987; Hardy et al. 1989; Hiebert et al. 1989, Thalmeier et al. 1989). E2F DNA binding activity is also elevated in extracts prepared from F9 stem cells (Reichel et al. 1987; Hardy et al. 1989) and 293 cells (Thalmeier et al. 1989). The induction of E2F DNA binding activity has been well correlated with increased transcription in vivo and in vitro that is dependent on intact E2F-binding sites (Imperiale and Nevins 1984; Imperiale et al. 1985; Kovesdi et al. 1986a,b, 1987; Hiebert et al. 1989; Loeken and Brady 1989; Thalmeier et al. 1989; Yee et al. 1989). The binding of E2F to two sites in the E2 promoter region appears to be cooperative (Yee et al. 1987; Hardy et al. 1989), and the induction of E2F binding activity by adenovirus is particularly evident 
when the E2 promoter region is examined (Kovesdi et al. 1986a,b; SivaRaman and Thimmappaya 1987; Hardy et al. 1989). The affinity of E2F to single binding sites is reduced compared to the double site in the E2 promoter region (Yee et al. 1987; Hardy et al. 1989; Hiebert et al. 19891.

The temporal regulation of adenovirus early gene expression has been analyzed extensively. Previous studies have demonstrated that the E2 promoter region contains multiple, independent regulatory elements. A TATAlike element is located at position - 25 (Murthy et al. 1985; Zalchowski et al. 1985). The two E2F-binding sites are inverted with respect to each other and are located centered at positions -40 and -65 (Kovesdi et al. 1986a,b; Yee et al. 1987, 1989; Hardy et al. 1989). A binding site for the cellular transcription factor, ATF, is located immediately upstream of the two E2F sites / $\mathrm{Si}$ vaRaman et al. 1986; Boeuf et al. 1987; SivaRaman and Thimmappaya 1987). Each of these elements contributes to the basal level of E2 expression (Elkaim et al. 1983; Imperiale and Nevins 1984; Imperiale et al. 1985; Murthy et al. 1985; Zajchowski et al. 1985; Jalinot and Kedinger 1986; Loeken and Brady 1989). E2 transcription is induced by the viral E1A gene products during viral infection and in a transient expression assay (for review, see Berk 1986; Nevins 1987). The activation of E2 expression by the E1A products apparently is based on redundant elements (Kingston et al. 1984; Murthy et al. 1985; Zajchowski et al. 1985; Jalinot and Kedinger 1986; Loeken and Brady 1989).

The binding of purified E2F to the E2 promoter in vitro is dependent on the phosphorylation state of E2F, and it has been suggested that the E1A proteins may induce a cellular protein kinase that phosphorylates E2F in vivo (Reichel et al. 1988; Bagchi et al. 1989). Other recent studies have shown that the expression of adenovirus early region 4 (E4) is required for efficient induction of E2F DNA binding activity (Babiss 1989; Hardy et al. 1989; Reichel et al. 1989). E2 transcription also was shown to be increased by E4 expression in vivo /Goding et al. 1985; Reichel et al. 1989). In this paper we demonstrate that the $\mathrm{E} 4$ open reading frame (ORF) 6/7 19.5-kD protein is physically involved in the induction of E2Fbinding to the $\mathrm{E} 2$ promoter via a direct interaction with this cellular protein. A peptide-specific antiserum, directed against the amino terminus of the $\mathrm{E} 419.5-\mathrm{kD}$ protein, altered the mobility of the adenovirus-induced E2F-E2 promoter complex in a gel shift assay. This effect was blocked using the cognate peptide to generate the antiserum. E2F DNA binding activity also was cleared from infected-cell nuclear extracts using this antiserum. E2F DNA binding activity was induced in the absence of viral E1A expression, demonstrating that the E1A products are not absolutely required for E2F induction. An induced, but altered, E2F-E2 promoter complex was detected in extracts from E4 ORF 6/7 mutantinfected cells indicating that an alternate pathway may lead to E2F induction in vivo. This possibility is consistent with recent studies /Reichel et al. 1988; Bagchi et al. 1989; Hardy et al. 1989), and suggests that adenovirus has adpated two different mechanisms for the induction of a cellular transcription factor.

\section{Results}

The E4 ORF 6/7 protein induces the DNA binding activity of E2F

Recently it was reported that adenovirus E4 is involved in the induction of E2F-binding to the E2 promoter and E1A enhancer regions (Babiss 1989; Hardy et al. 1989; Reichel et al. 1989). To extend this finding, we analyzed the induction of E2F DNA binding activity using wildtype adenovirus and a series of viral mutants with alterations in specific E4 ORFs and combinations of ORFs (Fig. 1). We used an exonuclease III protection assay and a gel mobility shift assay to distinguish E2F-E2 promoter complexes (Kovesdi et al. 1986a,b; Yee et al. 1987). The binding of E2F to the E2 promoter results in the protection of a 40-bp region from digestion with $E X$ -
Figure 1. E4 transcription unit map and mutant viruses. The Ad5 genomic map between 90 and 100 map units is shown (numbers above the heavy line). Nucleotide numbers relative to the right end of the genome are indicated (below the heavy line). The E4 transcription unit is transcribed in a right-to-left direction. The $\mathrm{E} 4$ cap site $(\mathrm{E} 4+1)$ and mRNA polyadenylation site $\left(E 43^{\prime}\right)$ are shown. E4 translational ORFs are indicated by shaded boxes and correspond to ORFs 1,2 , 3,4 , and 6 , and the fusion of ORFs $3 / 4$ and $6 / 7$ by mRNA splicing. The E4 mutant viruses described in the text are shown below the E4 schematic. Solid bars correspond to deletion mutations: dlORF1-4 (ORFs

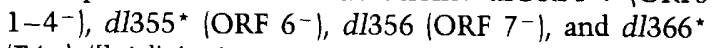
(E4-). ([loit]) An insertion mutation, inORF6,6/7 (ORFs $6^{-}$and $6 / 7^{-1}$. Mutant $d 1366^{*}+$ ORF $6 / 7$ contains an ORF $6 / 7$ cDNA in a $d 1366^{*}$ background. (*) The viral background used to construct the mutant viruses is shown (Huang and Hearing 1989).

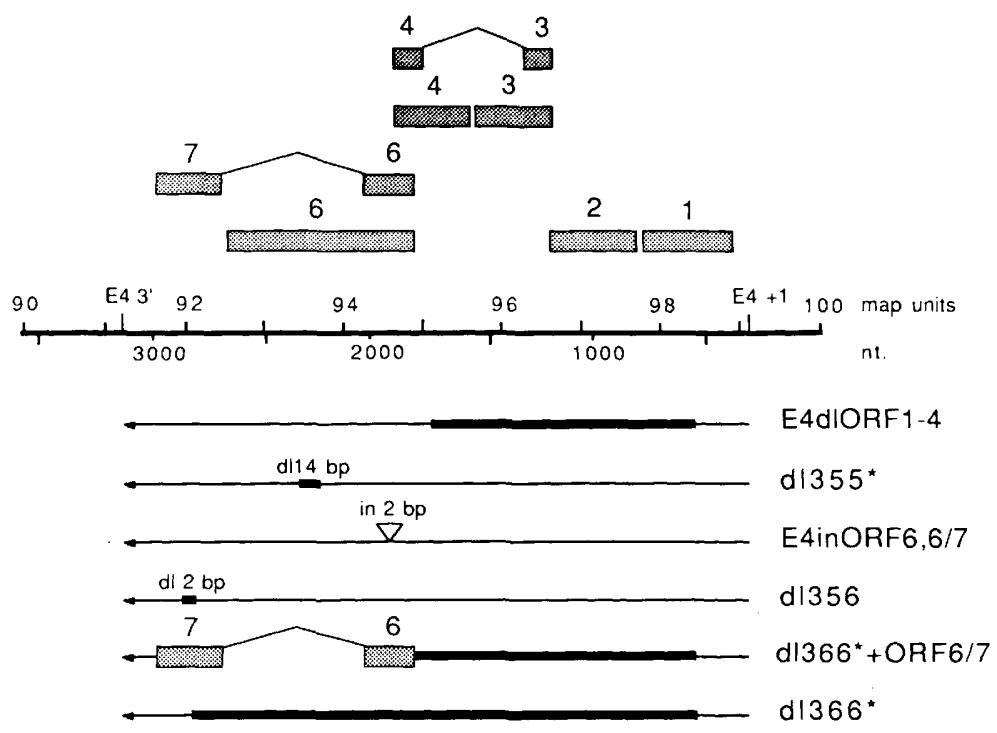


oIII; specific ExoIII stops were mapped previously at -71 and -33 (Kovesdi et al. 1986a,b; Reichel et al. 1987). Nuclear extracts, prepared from mock-infected, wild-type Ad5 (wt300)-infected, and mutant dl366* (E4-)-infected HeLa cells at early times after infection 16 $\mathrm{hr}$ ), were analyzed for the induction of E2F-binding to the E2 promoter region $(-98$ to -14 probe; Fig. 3, bottom). In the ExoIII assay (Fig. 2), the induction of E2F binding activity was clearly evident using wt300-infected cell extracts (ExoIII stops at -71 and -30 , Fig. $2 \mathrm{~A}, \mathrm{~B} \mid$, but E2F binding activity was at low levels in the mock-infected or $d 1366^{*}$-infected cell extracts. In longer exposures of these and similar gels, weak ExoIII stops at -71 and -30 were evident in the mock extracts and were present at a comparable level in the $d 1366^{\star}$ extracts (data not shown). The induction of E2F activity by the wild-type virus reached a peak by $6 \mathrm{hr}$ after infection and did not increase at later times (12 and $24 \mathrm{hr}$ postinfection; data not shown). These results are consistent with previous analyses (Kovesdi et al. 1986a,b; Reichel et al. 1988, 1989; Babiss 1989; Hardy et al. 1989).

Adenovirus E4 has the capacity to encode at least seven different polypeptides on the basis of the alternate splicing pattern of a primary transcription product (Fig.
1, ORFs 1-7; Virtanen et al. 1984). To determine which $\mathrm{E} 4$ product was involved in the induction of E2F binding activity, we utilized a set of mutant viruses that contain alterations in specific E4 open reading frames (Halbert et al. 1985; Huang and Hearing 1989). Using a gel mobility shift assay, the induction of E2F-binding to the E2 promoter $(-98$ to -14$)$ was evident in extracts prepared from wt300-infected HeLa cells but not from mock- and d1366*-infected cells (Fig. 3A). The doublet band representing the E2F-E2 promoter complex in the wild-type extracts was observed previously (Hardy et al. 1989). The specificity of this complex for E2F-binding was evident in competition experiments (Fig. 4). The adenovirus-induced E2F-E2 promoter complex was specifically competed using the homologous E2 promoter fragment, as well as the E1A enhancer region /that contains two E2Fbinding sites; Kovesdi et al. 1987; Hardy et al. 1989). A similar E1A enhancer region fragment, but containing deletions of both E2F sites, did not compete for E2Fbinding (Fig. 4; E1A 27/2). The binding of E2F to the E1A enhancer region was reduced 5- to 10-fold compared to the homolgous E2 fragment. An oligonucleotide containing an ATF-binding site (Leza and Hearing 1988) did not compete for E2F-binding (Fig. 4; ATF).
A.

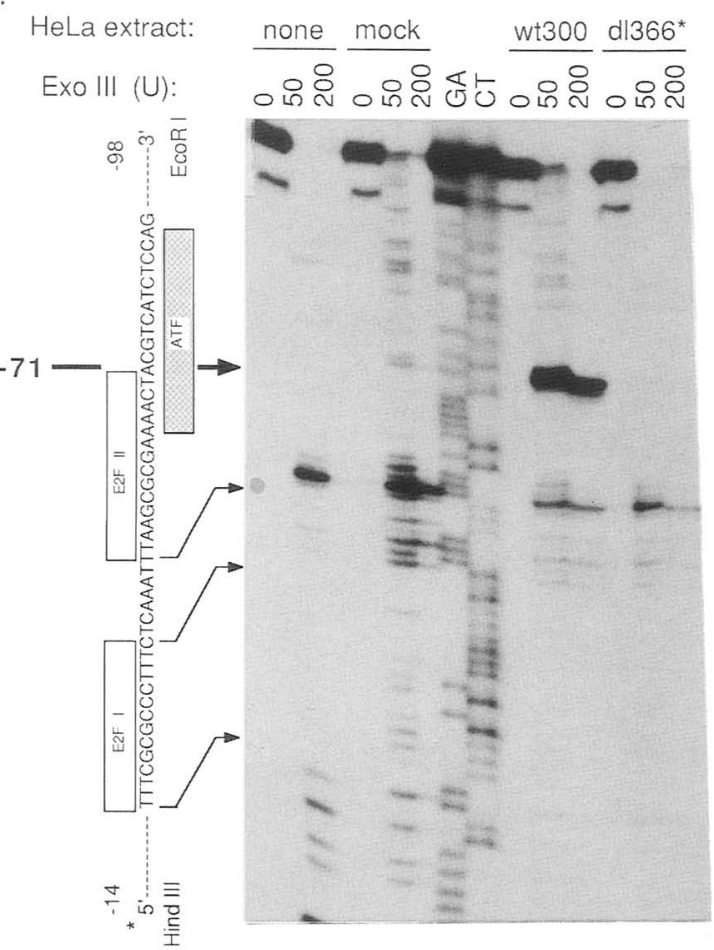

B.

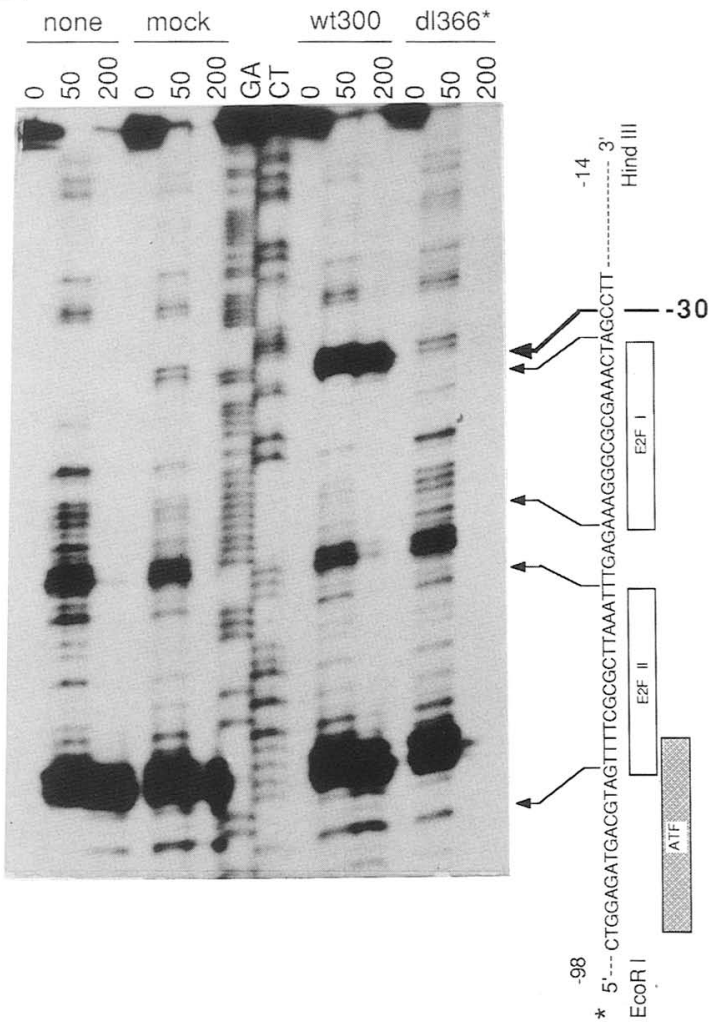

Figure 2. ExoIII protection assay for E2F binding activity. An E2 promoter fragment, ${ }^{32} \mathrm{P}-$ labeled at the downstream end $(-14, A)$ or the upstream end $(-98, B)$, was incubated with nuclear extracts prepared from mock-, wild-type- or dl366*-infected HeLa cells, or with no extract (none), in an E2F-binding reaction. Nuclear extracts were prepared $6 \mathrm{hr}$ after viral infection. Following the binding reaction, ExoIII was added $(0,50,200$ units $\mid$, and the reactions were incubated for $10 \mathrm{~min}$ at room temperature. The products were analyzed in an $8 \%$ polyacrylamide-urea gel. The positions of the ExoIII stop sites were determined by comparison with sequencing ladders (GA, CT) of the homologous fragment. The positions of the two E2F sites and ATF-binding site are drawn according to Yee et al. (1987) and SivaRaman et al. (1986). 


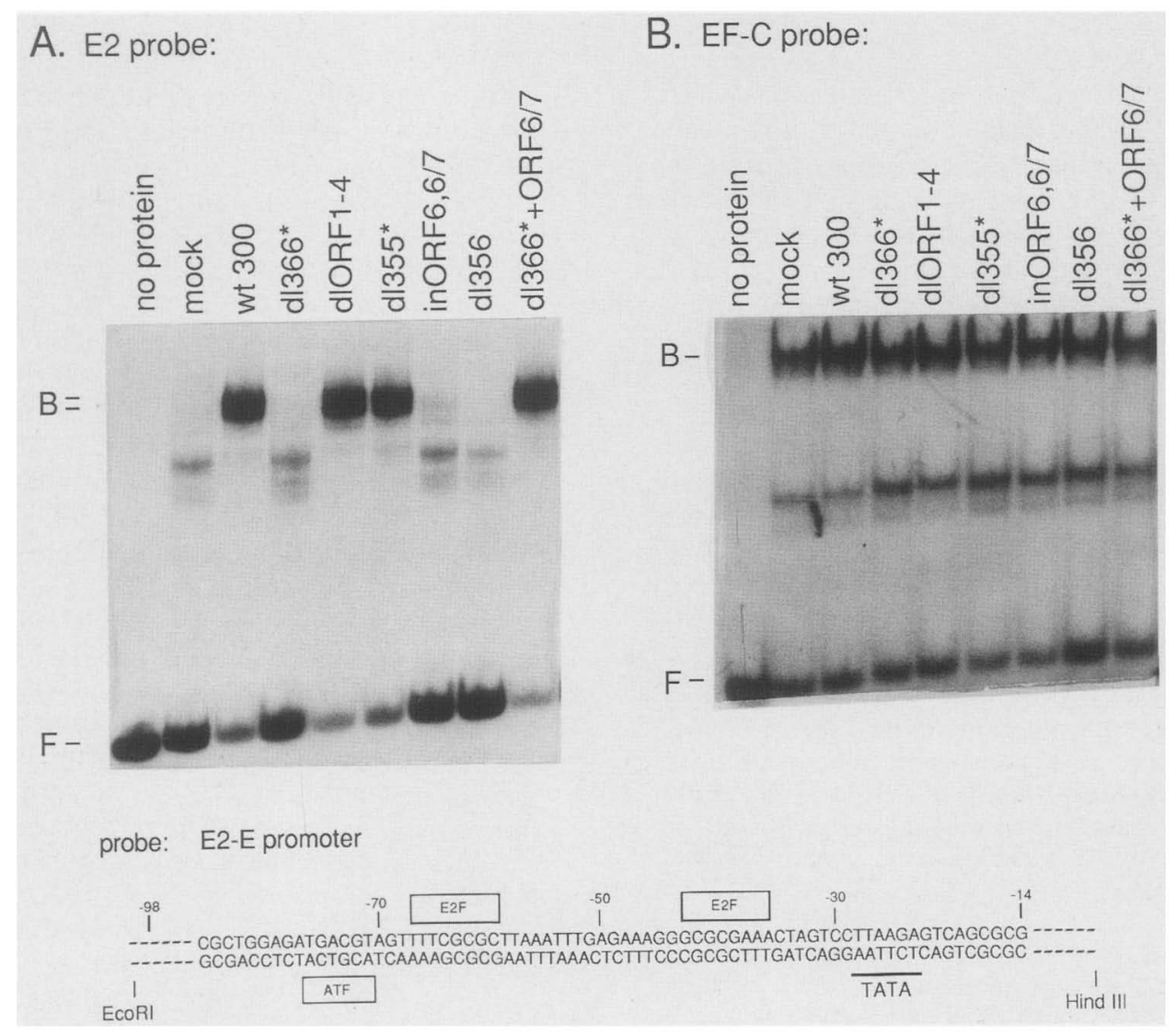

Figure 3. The E4 ORF 6/7 product is required for the induction of E2F binding activity. $(A)$ HeLa cells were mock-infected or infected with the viruses indicated. Nuclear extracts were prepared $6 \mathrm{hr}$ after infection and were subsequently incubated in an E2F-binding reaction with an E2 promoter probe (-98 to -14; sequence shown at bottom). The products of the binding reaction were electrophoresed in a polyacrylamide gel. (F) Free (unbound) probe DNA; (B) bound probe DNA. (B) The same nuclear extracts were incubated in binding reactions with an EF-C probe and analyzed as described in $A$.

Then we analyzed the induction of E2F activity with different E4 mutant viruses (Fig. 3A). A mutant virus that contains a deletion of $\mathrm{E} 4 \mathrm{ORFs} 1-4(d l \mathrm{ORF} 1-4)$ and expresses the products from ORFs 6 and 6/7 (Huang and Hearing 1989 | induced E2F binding activity to the same level as the wild-type virus. A mutant virus that contains a frame-shift mutation in ORF $6\left(d 1355^{*}\right)$ also induced E2F binding activity efficiently, whereas a virus that contains a frame-shift mutation in the region common to the ORF 6 and ORF 6/7 products (inORF6,6/ 7) was defective for E2F induction. These results sug. gested that the ORF $6 / 7$ product was responsible for the induction of E2F binding activity. This interpretation was confirmed because a virus with a frame-shift mutation in ORF 7 (dl356) was defective for E2F induction. Conclusively, a virus that contains an E4 ORF 6/7 cDNA in place of the E4-coding sequences $\left(d 1366^{\star}+\right.$ ORF6/7) induced E2F binding activity to the same level as that observed with the wild-type virus. The E4 ORF 6/7 cDNA was obtained from Ad2-infected cells (Virtanen et al. 1984). The virus carrying this cDNA synthesized an ORF $6 / 7$ product that was larger than the ORF 6/7 protein made in Ad5-infected cells (Fig. 7; wt300 and $d 1366^{\star}+$ ORF6/7) and that comi- grated with the ORF 6/7 protein synthesized in Ad2-infected cells (R. O'Connor and P. Hearing, unpubl.).

When each of these extracts was tested for the binding activity of a different nuclear DNA-binding protein, EF-C, which binds to the polyoma virus and hepatitis B virus enhancer regions (Ostapchuk et al. 1989), comparable binding activities were detected with all of the extracts (Fig. 3B). We conclude that the E4 ORF 6/7 product is required for efficient induction of E2F-binding to the E2 promoter.

\section{The E4 ORF 6/7 protein forms a complex with E2F in vitro}

Previously, we described a peptide-specific antiserum (R3) that is directed against the amino-terminal region of ORF 6 (amino acids 26-37; Cutt et al. 1987). This antiserum immunoprecipitates the ORF $634-\mathrm{kD}$ protein and the ORF 6/7 19.5-kD protein (Cutt et al. 1987). The addition of the R3 antiserum to an in vitro E2F-E2 promoter-binding reaction, using nuclear extract from wt300-infected HeLa cells, resulted in the formation of a complex with altered (reduced) gel mobility (Fig. 5A; R3, $1: 5,1: 25$, complex $B^{\star}$ ) relative to the complex ob- 


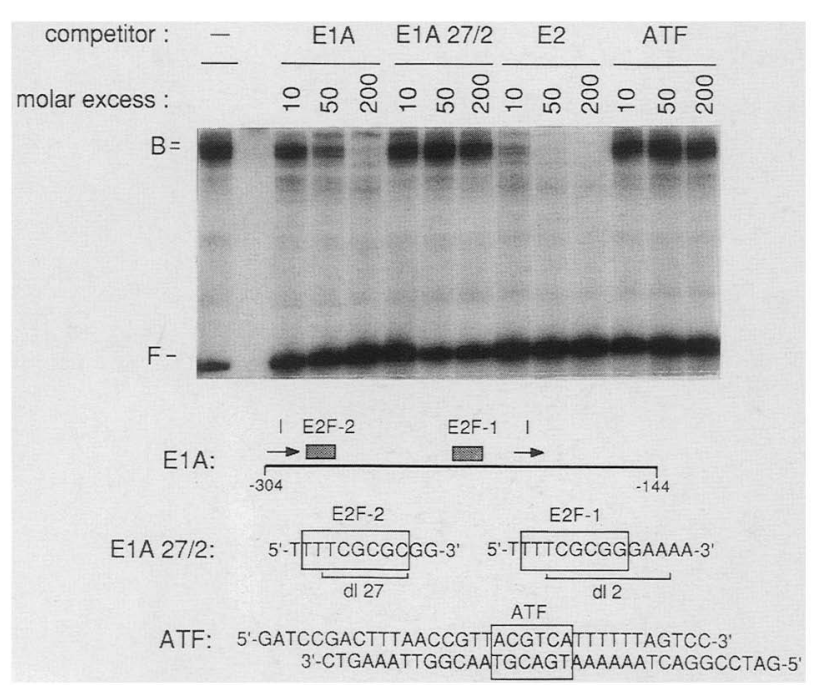

Figure 4. Competition for E2F-binding in the gel mobility shift assay. Nuclear extract, prepared from wt300-infected HeLa cells at $6 \mathrm{hr}$ after infection, was incubated in an E2Fbinding reaction with an E2 promoter probe $(-98$ to -14$)$. The binding reactions contained either no specific competitor DNA $1-)$ or increasing molar concentrations of specific competitor DNA fragments (10-, 50-, and 200-fold molar excess). The competitor DNA fragments were E1A, the E1A enhancer region $1-304$ to -144 , shown schematically below the autoradiogram) that contains two E2F-binding sites (E2F-1 and E2F-2); E1A 27/2, the same E1A enhancer region fragment that also contains deletions of the two E2F-binding sites (dl27 and $d l 2)$. The sequence of the two E2F sites in the E1A enhancer region and the two deletions are shown below the E1A enhancer region schematic. The extent of each deletion is indicated by a bracket below the sequence. (E2) The same fragment as the probe DNA; $(\mathrm{ATF})$, an oligonucleotide that contains the E4 ATF-binding site located at -50 . (F and B) Free and bound probe DNA, respectively.

served with the extract minus antiserum $(-)$ or with the addition of preimmune serum (NR3). Dilution of the R3 antiserum resulted in the reappearance of the normal adenovirus-induced E2F-E2 promoter complex (Fig. 5A; R3, $1: 100$ to $1: 1000$, B doublet). Incubation of the R3 antiserum with the extract before the binding reaction resulted in a similar shift in mobility of the E2F-E2 promoter complex, as shown in Figure 5A (data not shown). We also tested a second peptide-specific antiserum that is directed against the carboxy-terminal region of ORF 7 and that immunoprecipitates the ORF 6/7 19.5-kD product (R7 antiserum; Cutt et al. 1987). The addition of this antiserum to the E2F-E2 promoterbinding reaction or to the extract prior to the binding reaction did not alter the level or the mobility of the adenovirus-induced E2F-E2 promoter complex (data not shown). Neither antiserum (R3 or R7) affected the mobility of the EF-C complex when tested in EF-C binding reactions (data not shown, also see Fig. 6B).

To verify the specificity of the E2F-E2 promoter-R3 antibody complex, blocking experiments were performed (Fig. 5B) with the cognate peptide used to generate the R3 antiserum (peptide P2) or a nonspecific pep- tide (peptide P3) directed against a unique region of the ORF 6 product (Cutt et al. 1987). The addition of the R3 cognate peptide $(\mathrm{P} 2)$ to the in vitro-binding reaction blocked the effect of the R3 antibody on the adenovirusinduced E2F-E2 promoter complex (Fig. 5B; R3, 0 versus $\mathrm{R} 3+\mathrm{P} 2,1: 100,1: 1000$ ). Dilution of the cognate peptide (P2) in the binding reaction resulted in the reappearance of the $\mathrm{E} 2 \mathrm{~F}-\mathrm{E} 2$ promoter-R3 antibody complex $\left(\mathrm{B}^{*}\right.$; Fig. 5B, $\mathrm{R} 3$; P2, $1: 5000,1: 25,000)$. The addition of a nonspecific peptide (P3) did not alter the E2F-E2 promoter-R3 antibody complex, $\mathrm{B}^{*}$, at any dilution (Fig. $5 B ; R 3 ; P 3$. We conclude from these analyses and those presented above that the E4 ORF 6/7 protein is physically associated with E2F bound to the E2 promoter region. The R3 antiserum recognizes the ORF 6/7 protein in the complex with E2F, whereas the R7 antiserum does not recognize this complex.

These analyses did not distinguish whether the formation of the E4 ORF 6/7-E2F complex required prior binding of either component to the E2 promoter or whether the complex pre-existed in the nuclear extract. To address this question, we attempted to clear the nuclear extract of E2F binding activity using the R3 and R7 antisera. If the ORF 6/7 protein is in a complex with E2F in the nuclear extract, the R3 antiserum, but not the R7 antiserum, would be predicted to recognize this complex. Accordingly, nuclear extract, prepared from wt300infected HeLa cells, was incubated with either antisera (R3 or R7) or the preimmune sera (NR3 or NR7). Protein A-Sepharose was then added, and the antibody/protein A-Sepharose complexes were removed by successive centrifugations. The nuclear extract was then tested for E2F binding activity to the E2 promoter, and EF-Cbinding activity was analyzed as a control. The addition of protein A-Sepharose alone or together with the preimmune serum (NR3) had no effect on the level of E2F binding activity (Fig. 6A). Incubation of the nuclear extract with the $\mathrm{R} 3$ antiserum and subsequent clearing with protein A-Sepharose, however, resulted in a significant reduction of E2F binding activity (Fig. 6A). In contrast, the level of E2F binding activity was not reduced when the $\mathrm{R} 7$ antiserum was used in the clearing experiment (data not shown). EF-C binding activity in the nuclear extract was not affected by preincubation with the preimmune (NR3) or immune (R3) antisera, following the same procedure as described above (Fig. 6B). These analyses suggest that the formation of the ORF 6/7-E2F complex does not require DNA binding because the R3 antiserum, which recognizes this complex (Fig. 5), reduced E2F activity in the nuclear extract in the clearing experiment (Fig. 6A), whereas the $\mathrm{R} 7$ antiserum, which does not recognize this complex, did not affect E2F levels in this assay (data not shown).

The E1A proteins are not required for the formation of the E4 ORF 6/7-E2F complex

Expression of region E1A is required for optimal transcription of the other early regions after infection with adenovirus (for review, see Berk 1986; Nevins 1987). The 

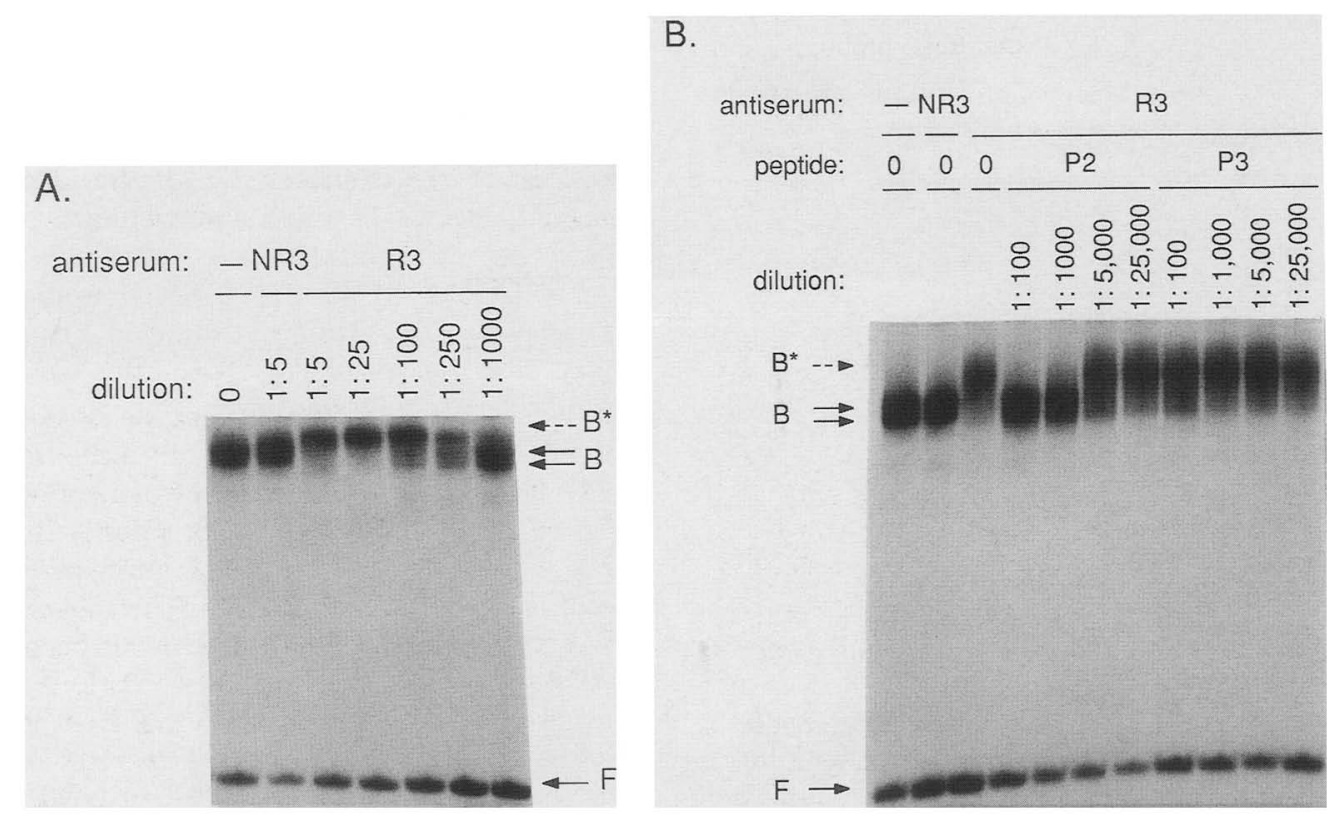

Figure 5. The E4 ORF 6/7 protein forms a complex with E2F bound to the E2 promoter. $(A)$ Nuclear extract, prepared from wt300-infected HeLa cells at $6 \mathrm{hr}$ after infection, was incubated in an E2F-binding reaction with an E2 promoter probe $(-98$ to -14$)$. After the binding reaction, the $\mathrm{R} 3$ antiserum or preimmmune serum (NR3) was added at the dilution indicated. The binding reaction-antibody mixture was incubated on ice for $1 \mathrm{hr}$, and the products were electrophoresed in an acrylamide gel. (Lane - ) The addition of no antiserum. $(B)$ The E2F-binding reactions and antiserum additions were the same as in $A$. Additionally, the binding reaction-antibody mixtures either contained no peptide $(0)$, dilutions of the $\mathrm{R} 3$ antiserum cognate peptide (P2), or a nonspecific peptide (P3). The products of the reactions were electrophoresed in a polyacrylamide gel. (F and B) Free and bound probe DNA, respectively; $\left(\mathrm{B}^{\star}\right)$ DNA-protein complex with altered mobility referred to in the text.

requirement for E1A expression for the induction of E2F binding activity (Kovesdi et al. 1986a,b), therefore, may represent an indirect effect where the ElA products are required for optimal expression of $\mathrm{E} 4$. The requirement for the ElA products during infection may be overcome by infection at high multiplicity; under these conditions, the other early regions are expressed at nearly wild-type levels (for review, see Berk 1986; Nevins 1987). Accordingly, we infected HeLa cells with a high mutliplicity (5000 particles/cell) of an E1A mutant virus (dl312; Jones and Shenk 1979) and examined the synthesis of the E4 ORF 6/7 product, as well as the induction of E2F binding activity at different times after infection (Figs. 7 and 8 ).

The E4 ORF 6/7 protein was clearly evident at $6 \mathrm{hr}$ after infection with the wild-type virus (Fig. 7; wt300, $\mathrm{R} 3$ ); this level did not change at later times after infection (Fig. 7; $12 \mathrm{hr}$; data not shown). The infection of HeLa cells with a high multiplicity of the ElA mutant virus, dl312, also resulted in the expression of the E4 ORF 6/7 protein, but at a reduced level compared to the wild-type virus (Fig. 7, dl312, R3). The level of the ORF $6 / 7$ protein increased as the dl312 infection progressed (Fig. 7; 6 and $12 \mathrm{hr}$; data not shown).

Then we prepared nuclear extracts from wild-type and mutant-infected HeLa cells at 6 and $12 \mathrm{hr}$ after infection. In these experiments, cytosine arabinoside (araC) was added to the medium to block viral DNA replication to avoid the complication that would arise if the wild-type and mutant viruses replicated at different rates. The addition of araC did not affect E2F induction with the wild-type virus (Fig. 8A). At $6 \mathrm{hr}$ after infection with dl312 at high multiplicity, the induction of E2F activity was clearly evident, although reduced compared with wild-type-infected cell extracts (Fig. 8A). By $12 \mathrm{hr}$ after infection with dl312, E2F activity was induced to within two- to threefold of the wild-type level of induction. This increase from 6 to $12 \mathrm{hr}$ correlated well with the increased expression of the ORF 6/7 protein in dl312-infected cells (Fig. 7). In this experiment and others, we noted that the d1312-induced E2F-E2 promoter complex predominantly corresponded to the lower form of the E2F-E2 promoter doublet. Because the nature of the E2FE2 promoter doublet has not yet been discerned, we do not understand the basis for this result. The E2F-E2 promoter complex formed using extracts from d1312-infected cells was specific for the E4 ORF 6/7 protein, as the addition of the $\mathrm{R} 3$ antiserum resulted in a reduction in the mobility of this DNA-protein complex (Fig. 8B; dl312, R3, band $\left.\mathrm{B}^{*}\right)$. This altered complex $\left(\mathrm{B}^{*}\right)$ was not observed when the cognate peptide $\mathrm{P} 2$ was included in the binding reaction with the R3 antiserum (Fig. 8B; dl312, R3; P2); again demonstrating that the complex contained the E4 ORF 6/7 protein.

As observed previously, essentially no E2F induction was evident in extracts from cells infected with the E4 mutant virus, $d 1366^{*}$, at $6 \mathrm{hr}$ after infection. In contrast, an E2F-specific complex was detected in extracts from 


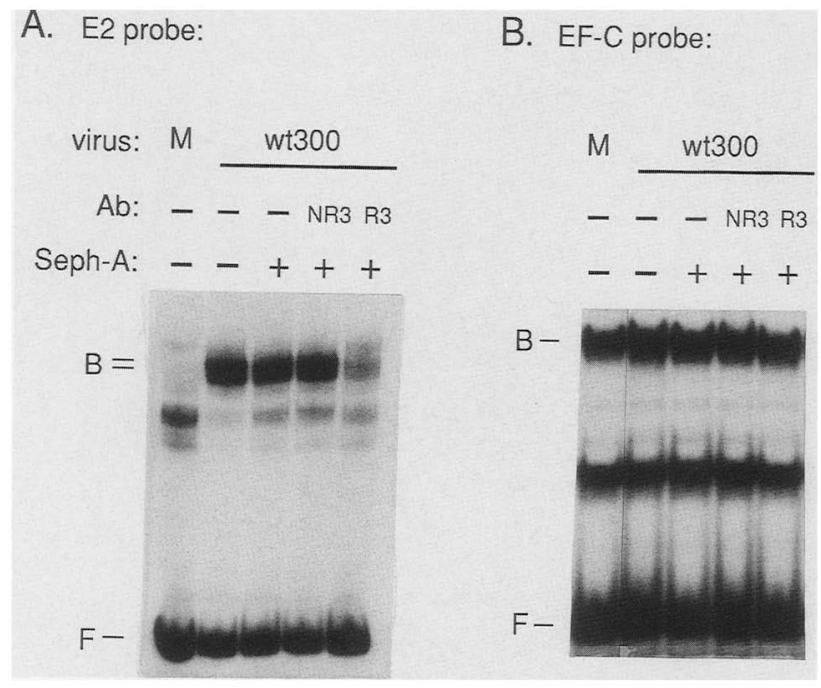

Figure 6. Clearing of E2F binding activity from nuclear extracts using the R3 antiserum. Nuclear extracts, prepared from wt300-infected HeLa cells at $6 \mathrm{hr}$ after infection, were incubated with no antibody $(-1$, preimmune serum (NR3, $1: 25 \mathrm{di}$ lution), or the ORF 6 peptide-specific antiserum (R3, 1:25 dilution) on ice for $1 \mathrm{hr}$. Following this incubation, protein ASepharose slurry was added and the mixtures were incubated at $4^{\circ} \mathrm{C}$ for $12 \mathrm{hr}$. The extracts were cleared of protein A-Sepharose by two successive centifugations, and the supernatant was assayed for E2F binding activity $(A)$ using an E2 promoter probe $(-98$ to -14$)$, or for EF-C binding activity $(B)$ using an EF-C probe. The products of the binding reactions were electrophoresed in an acrylamide gel. (Lanes $M$ ) Extracts prepared from mock-infected HeLa cells; (F and B) free and bound probe DNA, respectively.

d1366*-infected cells at $12 \mathrm{hr}$ after infection (Fig. 8A). This complex differed from the E2F activity induced by the wild-type virus in several ways. First, the $d 1366^{*}$-induced complex migrated as a single, although diffuse, species between the doublet observed using the wildtype virus. Second, $d 1366^{*}$ induced E2F activity to lower levels and with a delay compared to the wild-type virus. The complex induced by $d 1366^{\star}$ appeared to be E2F-specific because it was competed by the E2 promoter and E1A enhancer regions but not the E1A enhancer region that lacks the E2F-binding sites (data not shown). A similar, altered E2F-E2 promoter complex in extracts from dl366-infected cells was described recently (Hardy et al. 1989).

A mixed infection using $d 1312\left(\mathrm{E}^{\left.-\mathrm{A}^{-}\right)}\right.$and $d 1366^{*}\left(\mathrm{E} 4^{-}\right)$ resulted in the induction of E2F activity to wild-type levels, as expected, because these two viruses could complement each other in trans (Fig. 8A). In contrast, the in vitro mixing of extracts prepared from dl312-infected and $d 1366^{*}$-infected cells, prior to the binding reaction, did not increase E2F binding activity above the level observed using either individual extract (Fig. 8A; $d 1312+d 1366^{*}$ versus $d 1312$ or $\left.d 1366^{\star}\right)$. The same result was obtained when the extracts were mixed and incubated overnight (data not shown). Finally, we found no effect on the adenovirus-induced E2F-E2 promoter complex when monoclonal antibodies directed against different regions of the E1A proteins [monoclonal antibodies M73, M53, M1, or M3; Harlow et al. 1985 (kindly provided by Ed Harlow)] were incubated in the binding reaction (data not shown). These results and the mixing experiment are consistent with the idea that the ElA proteins are not directly involved in a complex with E2F.

\section{Discussion}

Transcription of the adenovirus early genes is subject to positive regulation by the viral E1A gene products. In this paper we demonstrate that the E4 ORF $6 / 719.5-\mathrm{kD}$ protein, a target for E1A trans-activation, also is involved in the regulatory scheme of adenovirus early gene expression. The E4 ORF 6/7 product is directly involved in the induction of the DNA binding activity of the cellular transcription factor, E2F. The adenovirus-mediated induction of E2F binding activity has been clearly linked with the activation of E2 transcription, cellular c-myc expression, and the activity of the E1A enhancer region (Imperiale and Nevins 1984; Imperiale et al. 1985; Kovesdi et al. 1986a,b, 1987; Hiebert et al. 1989; Loeken and Brady 1989; Thalmeier et al. 1989; Reichel et al. 1989; Yee et al. 1989). The induction of E2F binding activity by the E4 ORF $6 / 7$ protein is in agreement with other studies (Goding et al. 1985; Reichel et al. 1989) that demonstrated trans-activation of E2 expression by E4 in vivo.

We present several lines of evidence that the E4 ORF 6/7 product plays a major role in E2F induction through a direct complex with this cellular transcription factor. First, viral mutants that do not express the ORF 6/7 $19.5-\mathrm{kD}$ protein were deficient in E2F induction at early times after infection (Fig. 3A; $d 1366^{*}$, inORF6,6/7, and dl356). A virus that contains an ORF $6 / 7$ cDNA in place of the E4-coding sequences induced E2F binding activity as efficiently as the wild-type virus (Fig. 3A, $d 1366^{\star}+$ ORF6/7). Second, a peptide-specific antiserum (R3), which recognizes the amino terminus of the ORF 6/7 product, altered the mobility of the adenovirus-induced E2F-E2 promoter complex observed in a gel shift assay (Fig. 5A). This effect was not observed using the preimmune serum (Fig. 5A), and it was specifically blocked with the cognate peptide used to generate the R3 antiserum, but not by a nonspecific peptide (Fig. 5B). Finally, a nuclear extract prepared from adenovirus-infected cells was cleared of E2F binding activity using the ORF 6/7-specific R3 antiserum, but not the preimmune serum (Fig. 6A) or the ORF 6/7-specific R7 antiserum (data not shown). This latter result suggests that the formation of the E2F-ORF 6/7 complex does not require the prior binding of either component to DNA because the R3 antiserum recognizes the ORF 6/7-E2F complex (Fig. 5), whereas the R7 antiserum does not recognize this complex (data not shown). Because the E2F-binding assay is directly affected by the level of the ORF 6/7 protein, an alternative possibility may explain these results. In the clearing experiment, the ORF 6/7 protein may have been cleared from the nuclear extract independently of any bound E2F, and the assay actually reflected reduced E2F activity because of the loss of the ORF 6/7 
Figure 7. Expression of the E4 ORF $6 / 7$ protein in dl312 (E1A $\left.{ }^{-}\right)$mutant-infected cells. HeLa cells were mock-infected or infected with the viruses indicated. The multiplicity of infection was 200 particles/cell for viruses wt300 and $d 1366^{*}+$ ORF $6 / 7$ and 5000 particles/cell for mutant d1312. At 6 or 12 $\mathrm{hr}$ after infection, the cells were labeled using 200

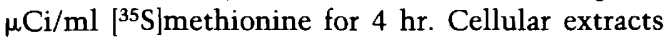
were prepared, and proteins were immunoprecipitated using the ORF 6 peptide-specific antiserum (R3) or preimmune serum (NR3). The products of the immunoprecipitation were electrophoresed in a $20 \%$ SDS-polyacrylamide gel, and subjected to fluorography. The positions of the Ad5 ORF $634-\mathrm{kD}$ protein and ORF $6 / 719.5 \cdot \mathrm{kD}$ protein are indicated adjacent to the autoradiogram. The position of the Ad2 ORF 6/7 synthesized by mutant $d 1366^{*}+$ ORF6/7 (ORF $\left.6 / 7^{\prime}\right)$ is also shown.

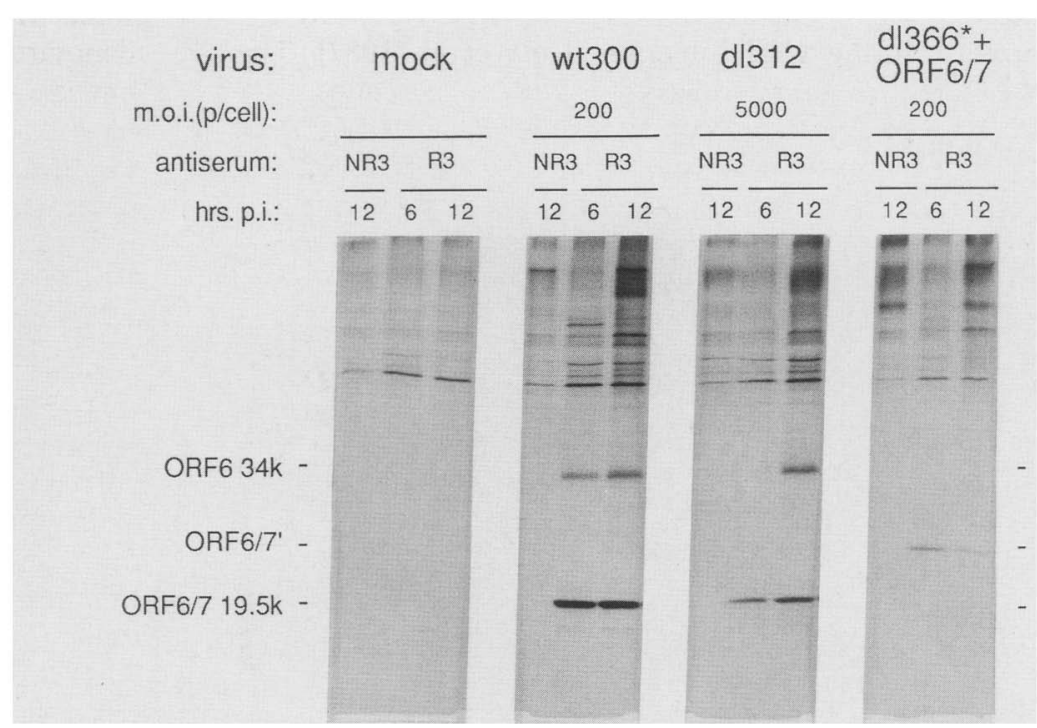

product, rather than the loss of an E2F-ORF 6/7 complex. This possibility seems unlikely, however, because the R7 antiserum did not have any effect on E2F levels in the clearing experiment. This result indicates that the ORF 6/7 protein does form a complex with E2F in solution since the R7 antiserum also would be expected to bind the soluble ORF 6/7 protein in the nuclear extract and reduce detectable E2F binding activity in this assay.

Our results suggest that the carboxy-terminal portion of the ORF $6 / 7$ product is involved in the interaction with E2F for several reasons. First, the adenovirus-in- duced E2F-E2 promoter complex was recognized by the R3 antiserum, which is directed against the amino terminus of ORF 6, but not the R7 antiserum, which is directed against the carboxyl terminus of ORF 7 . This indicates that the carboxyl terminus of the ORF $6 / 7$ product is not accessible for antibody binding while in contact with E2F. Second, mutant virus d1356, which contains a frame-shift mutation in ORF 7, was completely defective for E2F induction at early times after infection (Fig. 3A). We demonstrated previously that this virus produces a stable truncated ORF $6 / 7$ product that
Figure 8. Induction of E2F binding activity in the absence of the E1A proteins. $(A)$ HeLa cells were mock-infected or infected with the viruses indicated. The multiplicity of infection was 400 particles/cell for viruses wt 300 and $d 1366^{*}$ and 5000 particles/cell for mutant dl312. (Lane $d 1312 / d l 366^{*}$ ) A mixed infection of both mutant viruses is shown. After viral infection, medium was added that contained $25 \mu \mathrm{g} / \mathrm{ml}$ araC. Nuclear extracts were prepared at 6 or $12 \mathrm{hr}$ after infection and assayed for E2F binding activity using an E2 promoter probe $(-98$ to -14$)$. (Lane $\left.d 1312+d 1366^{*}\right)$ The in vitro mixing of nuclear extracts prepared from individual viral infections is shown, as described in the text. The products of the binding reaction were electrophoresed in a polyacrylamide gel. (F and B) Free and bound probe DNA, respectively. (B) Nuclear extracts, prepared from mock-infected HeLa cells or $\mathrm{HeLa}$ cells infected with wt 300 or $d 1312$ at $12 \mathrm{hr}$ after infection, were used in an E2F-binding reaction as described in $A$. After the binding reaction, either no antiserum (0), the ORF 6 peptide-specific antiserum (R3, 1:25 dilution), or R3 antiserum plus the cognate peptide (P2, $1: 100$ dilution) was added, and the mixture was incubated on ice for $1 \mathrm{hr}$. The products of the binding reactions were analyzed in a polyacrylamide gel. (F, B, and $\left.\mathrm{B}^{\star}\right)$ Free, bound, and bound plus antibody probe DNA, respectively.

accumulates to the same level as the wild-type ORF 6/7 protein during viral infection (Cutt et al. 1987). The truncated product, however, does not induce E2F binding activity. Finally, the ORF $634-\mathrm{kD}$ protein shares 58 amino-terminal amino acids with the ORF 6/7 product, yet the ORF 6 protein is not involved in E2F

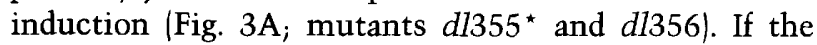
amino terminus of ORF 6 was involved in the interaction with E2F, the ORF 6 product might substitute for the ORF 6/7 product with mutant $d 1356$. These interpretations are limited by conformational differences that may exist between the different polypeptides described, but clearly the carboxy-terminal region of the ORF $6 / 7$ protein is essential for E2F induction.

A number of analyses have demonstrated that the adenovirus E2 promoter is trans-activated by the viral ElA gene products in the absence of E4 expression (Kingston et al. 1984; Imperiale et al. 1985; Murthy et al. 1985; Zajchowski et al. 1985; Loeken and Brady 1989). E1A-mediated induction of E2 transcription may involve the ATF-binding site in the E2 promoter region (Sassone-Corsi 1988). Elevated levels of E2F activity were detected in 293 cells /which express the E1A and E1B proteins) compared to HeLa cells when E2F-binding to the c-myc promoter was examined (Thalmeier et al. 1989). The recent observation that the phosphorylation state of purified E2F influences the DNA binding activity of this protein has led to the suggestion that the E1A products may induce a cellular protein kinase that phosphorylates E2F (Reichel et al. 1988; Bagchi et al. 1989). Thus, the E1A products activate E2 transcription and may induce E2F DNA binding activity, independently of the E4 ORF $6 / 7$ protein. Our results clearly show that the DNA binding activity of E2F is induced in the absence of E1A expression. The high multiplicity of infection of HeLa cells with an E1A mutant virus, dl312, resulted in readily detectable E2F induction by $12 \mathrm{hr}$ after infection (Fig. 8A) that was clearly dependent on the ORF $6 / 7$ product (Fig. 8B). Thus, it appears that adenovirus has developed two different mechanisms for the induction of E2F binding activity. One mechanism involves the interaction of E2F with a viral gene product; the second may involve phosphorylation of E2F by an adenovirus-induced cellular protein kinase. The induction of E2F in HeLa cells infected with a high multiplicity of mutant $d 1312$ was not observed by Kovesdi et al. (1986b) and was only observed with a considerable delay by Hardy et al. (1989; 36-48 hr after infection). We do not understand the differences obtained by the three groups in this regard, but it may reflect the use of different lines of Hela cells in the studies or variations in the E2F assay conditions.

An E2 promoter-protein complex was observed in extracts prepared from $d 1366^{\star}$-infected cells at $12 \mathrm{hr}$ after infection, which was not detected at earlier times after infection with this mutant virus (Fig. 8A). This complex appears to involve E2F, as it was specifically competed by the E2 promoter and wild-type E1A enhancer regions but not by the E1A enhancer region that lacks the two E2F-binding sites (data not shown). This complex mi- grated with altered mobility compared to the wild-type adenovirus-induced E2F-E2 promoter complex (migration as a diffuse single band), and it was induced with a lag compared to the wild-type-induced E2F activity. Hardy et al. (1989) also observed an altered E2F-E2 promoter complex in extracts prepared from d1366-infected cells. The E2F induction observed in d1366-infected cells at $12 \mathrm{hr}$ after infection could relate to normal ElA transactivation because the ElA products likely activate viral transcription at multiple levels and, possibly, at different stages of infection. The induction of this E2F activity may represent the phosphorylation-mediated E2F induction cited above.

The expression of an E4 gene product during adenovirus infection increases considerably the half-life of E2F bound to the E2 promoter region (Hardy et al. 1989). On the basis of our analyses, we would attribute this effect to the E4 ORF 6/7 protein. The two E2F-binding sites in the $\mathrm{E} 2$ promoter region are inverted with respect to each other, and adenovirus-induced E2F-binding to these sites appears to be cooperative (Yee et al. 1987; Hardy et al. 1989). We speculate that the function of the E4 ORF 6/7 protein in the induction of E2F binding activity is to enhance the cooperative interaction of two E2F molecules at the E2 promoter-binding sites. This could be accomplished in several ways. The ORF $6 / 7$ protein may form a complex with two E2F molecules in solution and thereby stimulate the cooperative binding of E2F by increasing the probability that two E2F molecules interact with the E2 promoter region simultaneously. The ORF 6/7 protein could bridge two E2F molecules at the E2 promoter and stablize their interaction with DNA. Finally, the ORF $6 / 7$ protein may recognize the E2 promoter directly and enhance the binding of E2F to its binding motif. Future analyses will be required to address the mechanism of ORF 6/7 action. Several analogies may be drawn with the formation of the E4 ORF 6/7-E2F complex. The herpes simplex virus (HSV) VP16 protein activates transcription of HSV immediate early genes via a cellular DNA-binding protein (OBP/OCT; for review, see Schaffner 1989) and the TAATGARAT sequence motif (McKnight et al. 1987; O'Hare and Goding 1988; Preston et al. 1988; Triezenberg et al. 1988). VP16 may influence the DNA binding activity of OBP/OCT to the TAATGARAT sequence (Preston et al. 1988). The E4 ORF 6/7-E2F complex may also resemble the interaction of Fos and Jun molecules at an AP1-binding motif where the heterodimeric interaction of these two molecules enhances the interaction of each with DNA (Halazonetis et al. 1988, Nakabeppu et al. 1988). Whether the E4 ORF $6 / 7$ protein supplants a cellular gene product that normally interacts with E2F for binding to cellular promoter sequences remains to be determined.

\section{Materials and methods}

Cells and viruses

Suspension cultures of HeLa cells were maintained in suspension-modified minimal essential medium containing $7 \%$ calf serum. Monolayer cultures of 293 cells (Graham et al. 1977) and 
W162 cells (Weinberg and Ketner 1983) were maintained in Dulbecco's modified Eagle's medium containing $10 \%$ calf serum. Adenovirus wt300 and mutants $d 1312$ and $d 1356$ were described previously (Jones and Shenk 1979; Halbert et al. 1985). E4 mutants E4dlORF1-4, dl355*, E4inORF6,6/7, and d1366* were described recently (Huang and Hearing 1989). The asterisk (*) adjacent to several of the mutant names reflects the $\mathrm{E} 3+$ viral background used to construct the mutant viruses (Huang and Hearing 1989). E4 mutant $d 1366^{*}+$ ORF6/7 was constructed using a cDNA corresponding to Ad2 E4 ORF 6/7 (clone 101; Virtanen et al. 1984; kindly provided by M. Perricaudet). The E4 ORF 6/7 cDNA was inserted in a plasmid that contains the right $25 \%$ of the Ad5 genome and deletion dl366 in region E4 (Halbert et al. 1985; E4- phenotype), using ClaI linkers. The E4 ORF 6/7 clone was reconstructed into an intact virus as described (Huang and Hearing 1989). The wild-type virus and mutant $d 1312$ were propagated in 293 cells; E4 mutant viruses were propagated in W162 cells. Viral infections were performed using 500 particles/cell (unless noted otherwise), as described (Huang and Hearing 1989), and the cells were harvested at the time points indicated in the figure legends.

Probe and competitor DNAs, nuclear extracts, and DNA-protein-binding reactions

Plasmid pUC-E2 contains the Ad5 E2 sequences from the NarI site at -98 to the BssHII site at -14 cloned into the polylinker region of pUC9. The E2 promoter fragment was labeled at either the EcoRI site (E2 - 98 proximal) or HindIII site (E2 - 14 proximal) and released from the vector with the other enzyme (HindIII or EcoRI, respectively). The probes for mobility shift analyses were 3 '-end-labeled using $\left[\alpha^{-32} \mathrm{P}\right] \mathrm{dATP}$ and Klenow DNA polymerase. The probes for the ExoIII assays were 5 '-endlabeled using $\left[\gamma^{-32} \mathrm{P}\right] \mathrm{ATP}$ and T4 kinase. A synthetic oligonucleotide (29-mer) that contains the polyomavirus EF-C-binding site (Ostapchuk et al. 1989) was 3'-end-labeled using $\left[\alpha^{-32} \mathrm{P}\right] \mathrm{dATP}$ and Klenow DNA polymerase. The specific activity of the probes ranged from $0.5 \times 10^{4}$ to $1.0 \times 10^{4} \mathrm{cpm} /$ fmole. All probe DNAs were electroeluted from polyacrylamide gels and precipitated with ethanol three times.

The following competitor plasmid DNAs and oligonucleotides were used. pUC-E1A-WT contains the Ad5 RsaI (nucleotide 195)-to-SstII (nucleotide 353) fragment cloned in pUC9. Mutant plasmid pUC-E1A-27/2 is the same fragment in pUC9 and also contains deletions $d l 27$ and $d l 2$ in the E2F-binding sites (Bruder and Hearing 1989; see Fig. 4, bottom). The E1A enhancer region fragments were released from the vectors by EcoRI and HindIII digestion, and the competitor DNAs were purified as described above. A synthetic oligonucleotide (35mer) containing the E4 ATF-binding site $(-63$ to -34$)$ was described previously (Leza and Hearing 1988).

Nuclear extracts were prepared according to the procedure of Dignam et al. (1983). E2F-binding reactions (15 $\mu$ l) contained 20 mM HEPES ( $\mathrm{pH} 7.6$ ), $40 \mathrm{~mm} \mathrm{KCl}, 1 \mathrm{mM} \mathrm{MgCl}_{2}, 0.5 \mathrm{~mm}$ dithiotrethitol (DTT), $0.1 \mathrm{mM}$ EGTA, 4\% (wt/vol) Ficoll, $0.1-0.2 \mu \mathrm{g}$ of labeled DNA $(10,000 \mathrm{cpm}, 1-2$ fmoles $)$, and $2 \mu \mathrm{g}$ of sheared salmon sperm DNA as a nonspecific competitor (Kovesdi et al. 1986). Binding reactions were initiated by the addition of nuclear extract $(8-16 \mu \mathrm{g})$, and the reactions were incubated at room temperature for $30 \mathrm{~min}$. DNA-protein complexes were resolved in a $4 \% 30: 1$ polyacrylamide gel electrophoresed in $0.5 \times$ TBE $[25 \mathrm{~mm}$ Tris- $\mathrm{HCl}(\mathrm{pH} 8.3), 25 \mathrm{~mm}$ boric acid, $1 \mathrm{mM}$ EDTA] at $4^{\circ} \mathrm{C}$. EF-C-binding reactions $(15 \mu)$ contained 20 mM HEPES (pH 7.6), $40 \mathrm{~mm} \mathrm{KCl,} 5 \mathrm{~mm} \mathrm{MgCl}_{2}, 0.5 \mathrm{~mm} \mathrm{DTT}$, $5000 \mathrm{cpm}$ of labeled oligonucleotide $(0.5-1 \mathrm{fmole}), 2.0 \mu \mathrm{g}$ of poly $[\mathrm{d}(\mathrm{I}-\mathrm{C})]$ as a nonspecific competitor, and $2-4 \mu \mathrm{g}$ of nuclear extract. EF-C-binding reactions were performed and analyzed as described (Ostapchuk et al. 1989)

The ExoIII protection assays (Wu 1985) were performed as described by Kovesdi et al. (1986a,b). Following E2F binding, the reactions were treated with increasing concentrations of ExoIII (Pharmacia) for $10 \mathrm{~min}$ at room temperature. The reactions were subsequently extracted with phenol/chloroform, and the DNA precipitated with ethanol. The products were analyzed on an $8 \%$ polyacrylamide-urea gel.

\section{Immunoprecipitations and antibody-binding reactions}

The R3 antiserum is a rabbit antiserum that is directed against a peptide (P2) containing amino-terminal sequences from E4 ORF 6 (amino acids 26-37), and has been described (Cutt et al. 1987). For immunoprecipitations, HeLa cells were infected at 200 particles/cell for wt 300 and $d 1366^{*}+$ ORF6/7 and at 5000 particles/cell for dl312. At 6 or $12 \mathrm{hr}$ after infection, the cells were labeled with $\left[{ }^{35} \mathrm{~S}\right]$ methionine $(200 \mu \mathrm{Ci} / \mathrm{ml})$ for $4 \mathrm{hr}$. Cellular extracts were prepared by lysis in RIPA buffer as described previously (Cutt et al. 1987). Immunoprecipitations using the R3 antiserum or the preimmune serum from the same rabbit (NR3) were performed as described (Cutt et al. 1987), and the products were anlayzed in a $20 \%$ SDS-polyacrylamide gel (Cutt et al. 1987).

The following conditions were used for the incubation of antiserum with the E2F or EF-C-binding reactions. The DNAprotein-binding reactions were performed as described above. The binding reactions were then placed on ice, and $1 \mu l$ of the dilutions of antisera indicated in the figures was added. The E2F-binding reactions plus antisera were incubated on ice for 1 $\mathrm{hr}$, and the samples were then analyzed on a $4 \% 30: 1$ polyacrylamide gel as described above. Peptides P2 and P3 were described previously (Cutt et al. 1987) and were included in blocking reactions $(1 \mu l)$ at the dilutions indicated in the figures or in the figure legends. The following conditions were used to clear the nuclear extracts of E2F binding activity using the R3 antiserum. Nuclear extracts were incubated on ice for $1 \mathrm{hr}$ with $1 \mu \mathrm{l}$ of the dilution of antiserum indicated in the figures. Two microliters of a $2 \%$ slurry of protein A-Sepharose (Pharmacia) was then added and the sample was incubated for $12 \mathrm{hr}$ at $4^{\circ} \mathrm{C}$. The Sepharose beads were then precipitated by two successive centrifugations in a microfuge. The final supernatant was analyzed for E2F or EF-C activity as described above.

\section{Acknowledgments}

We are very grateful to Michel Perricaudet for the E4 ORF 6/7 cDNA and to Ed Harlow for the ElA monoclonal antibodies and for helpful suggestions. We thank our colleagues for many helpful discussions, Philomena Ostapchuk for the EF-C probes, Joseph Bruder for advice concerning E2F-binding reactions, Aleida Leza for the ATF oligonucleotide, and Janet Hearing for the protein A-Sepharose. We thank Tina Philipsberg for excellent technical help. This work was supported by U.S. Public Health Service grant CA28146 to P.H.

\section{References}

Babiss, L.E. 1989. The cellular transcription factor E2F requires viral ElA and E4 gene products for increased DNA-binding activity and functions to stimulate adenovirus E2A gene gxpression. J. Virol. 63: 2709-2717.

Bagchi, S., P. Raychaudhuri, and J.R. Nevins. 1989. Phosphorylation-dependent activation of the adenovirus-inducible E2F transcription factor in a cell-free system. Proc. Natl. Acad. Sci. 86: $4352-4356$. 
Berk, A.J. 1986. Adenovirus promotes and Ela transactivation. Annu. Rev. Genet. 20: 45-79.

Boeuf, H., D.A. Zajchowski, T. Tamura, C. Hauss, and C. Kedinger. 1987. Specific cellular proteins bind to critical promoter sequences of the adenovirus early EIIa promoter. $\mathrm{Nu}$ cleic Acids Res. 15: 509-527.

Bruder, J.T. and P. Hearing. 1989. Nuclear factor EF-1A binds to the adenovirus E1A core enhancer element and to other transcriptional control regions. Mol. Cell. Biol. (in press).

Cutt, J.R., T. Shenk, and P. Hearing. 1987. Analysis of adenovirus early region 4-encoded polypeptides synthesized in productively infected cells. J. Virol. 61: 543-552.

Dignam, J.D., R.M. Lebovits, and R.G. Roeder. 1983. Accurate transcription initiation by RNA polymerase II in a soluble extract from isolated memmalian nuclei. Nucleic Acids Res. 11: $1475-1489$.

Elkaim, R., C. Goding, and C. Kedinger. 1983. The adenovirus-2 EIIa early gene promoter: Sequences required for efficient in vitro and in vivo transcription. Nucleic Acids Res. 11: $7105-7117$.

Goding, C., P. Jalinot, D. Zajchowski, H. Boeuf, and C. Kedinger. 1985. Sequence-specific trans-activation of the adenovirus EIIa early promoter by the viral EIV transcription unit. EMBO I. 4: 1523-1528.

Graham, F.L., J. Smiley, W.C. Russell, and R. Nairu. 1977. Characteristics of a human cell line transformed by DNA from human adenovirus type 5. J. Gen. Virol. 36: 59-72.

Halazonetis, T.D., K. Georgopoulos, M.E. Greenberg, and P. Leder. 1988. c-Jun dimerizes with itself and with c-Fos, forming complexes of different binding affinities. Cell 55: $917-924$.

Halbert, D.N., J.R. Cutt, and T. Shenk. 1985. Adenovirus early region 4 encodes functions required for efficient DNA replication, late gene expression, and host cell shutoff. I. Virol. 56: $250-257$.

Hardy, S., D.A. Engel, and T. Shenk. 1989. An adenovirus early region 4 gene product is required for induction of the infection-specific from of cellular E2F activity. Genes Dev. 3:1062-1074.

Harlow, E., B.R. Franza Jr., and C. Schley. 1985. Monoclonal antibodies specific for adenovirus early region $1 \mathrm{~A}$ proteins: extensive heterogeneity in early region 1A products. J. Virol. 55: 533-546.

Hiebert, S.W., M. Lipp, and J.R. Nevins. 1989. E1A-dependent trans-activation of the human MYC promoter is mediated by the E2F factor. Proc. Natl. Acad. Sci. 86: 3594-3598.

Huang, M.M. and P. Hearing. 1989. Adenovirus early region 4 encodes two gene products with redundant effects in lytic infection. I. Virol. 63: 2605-2615

Imperiale, M.J. and J.R. Nevins. 1984. Adenovirus 5 E2 transcription unit: an E1A-inducible promoter with an essential element that functions independently of position and orientation. Mol. Cell. Biol. 4: 875-882.

Imperiale, M.J., R.P. Hart, and J.R. Nevins. 1985. An enhancerlike element in the adenovirus E2 promoter contains sequences essential for uninduced and E1A-induced transcription. Proc. Natl. Acad. Sci. 82: 381-385.

Jalinot, P. and C. Kedinger. 1986. Negative regulatory sequences in the E1A-inducible enhancer of the adenovirus-2 early EIIa promoter. Nucleic Acids Res. 14: 2651-2669.

Jones, N. and T. Shenk. 1979. Isolation of adenovirus type 5 host range deletion mutants defective for transformation of rat embryo cells. Cell 17: 683-689.

Kingston, R.E., R.J. Kaufman, and P.A. Sharp. 1984. Regulation of transcription of the adenovirus EII promoter by Ela gene products: Absence of sequence specificity. Mol. Cell. Biol. 4: $1970-1977$.

Kovesdi, I., R. Reichel, and J.R. Nevins. 1986a. E1A transcription induction: Enhanced binding of a factor to upstream promoter sequences. Science 231: 719-722.

- 1986b. Idendification of a cellular transcription factor involved in E1A trans-activation. Cell 45: 219-228.

1987. Role of the promoter-specific factor E2F in E1Amediated coordinate gene control. Proc. Natl. Acad. Sci. 84: 2180-2184.

Leza, M.A. and P. Hearing. 1988. Cellular transcription factor binds to adenovirus early region promoters and to a cyclic AMP response element. J. Virol. 62: 3003-3013.

Loeken, M.R. and J. Brady. 1989. The adenovirus EIIA enhancer: analysis of regulatory sequences and changes in binding activity of ATF and EIIF following adenovirus infection. J. Biol. Chem. 264: 6572-6579.

McKnight, J.L.C., T.M. Kristie, and B. Roizman. 1987. Binding of the virion protein mediating alpha gene induction in herpes simplex virus-1 infected cells to its cis site requires cellular proteins. Proc. Natl. Acad. Sci. 84: 7061-7065.

Murthy, S.C.S., G.P. Bhat, and B. Thimmappaya. 1985. Adenovirus EIIA early promoter:transcription control elements and induction by the viral pre-early E1A gene which appears to be sequence independant. Proc. Natl. Acad. Sci. 82: $2230-2234$.

Nakabeppu, Y., K. Ryder, and D. Nathans. 1988. DNA-binding activities of three murine Jun proteins: Stimulation by Fos. Cell 55: 907-915.

Nevins, J.R. 1987. Regulation of early adenovirus gene expression. Microbiol. Rev. 51: 419-430.

O'Hare, P. and C.R. Goding. 1988. Herpes simplex virus regulatory elements and the immunoglobulin octamer domain bind a common factor and are both targets for virion transcription. Cell 52: 435-445.

Ostapchuk, P., G. Scheirle, and P. Hearing. 1989. Binding of nuclear factor EF-C to a functional domain of the hepatitis B virus enhancer region. Mol. Cell. Biol. 9: 2787-2797.

Preston, C.M., M. Frame, and M.E.M. Campbell. 1988. A complex formed between cell components and an HSV structural polypeptide binds to a viral immediate early gene regulatory DNA sequence. Cell 52: 425-434.

Reichel, R., I. Kovesdi, and J.R. Nevins. 1987. Developmental control of a promoter-specific factor that is also regulated by the ElA gene product. Cell 48: 501-506.

- 1988. Activation of a preexisting cellular factor as a basis of adenovirus E1A-mediated transcription control. Proc. Nat1. Acad. Sci. 85: 378-390.

Reichel, R., S.D. Neill, I. Kovesdi, M.C. Simon, P. Raychaudhuri, and J.R. Nevins. 1989. The adenovirus E4 gene, in addition to the E1A gene, is important for trans-activation of E2 transcription and for E2F activation. I. Virol. 63: 36433650.

Sassone-Corsi, P. 1988. Cyclic AMP induction of early adenovirus promoters involves sequences required for E1A transactivation. Proc. Natl. Acad. Sci. 85: 7192-7196.

Schaffner, W. 1989. How do different transcription factors binding the same DNA sequence sort out their jobs? Trends Genet. 5: 37-39.

SivaRaman, L. and B. Thimmappaya. 1987. Two promoter-specific host factors interact with adjacent sequences in an E1A-inducible adenovirus promoter. Proc. Natl. Acad. Sci. 84: 6112-6116.

SivaRaman, L. S. Subrananian, and B. Thimmappaya. 1986. Identification of a factor in Hela cells specific for an upstream transcriptional control sequence of an Ela-inducible 


\section{Huang and Hearing}

adenovirus promoter and its relative abundance in infected and uninfected cells. Proc. Natl. Acad. Sci. 83: 5914-5918.

Thalmeier, K., H. Synovzik, R. Mertz, E.L. Winnacker, and M. Lipp. 1989. Nuclear factor E2F mediates basic transcription and trans-activation by Ela of the human MYC promoter. Genes Dev. 3: 527-536.

Triezenberg, S.J., K.L. LaMarco, and S. McKnight. 1988. Evidence of DNA : protein interactions that mediate HSV-1 immediate early gene activation by VP16. Genes Dev. 2: 730742.

Virtanen, A., P. Gilardi, A. Naslund, J.M. Lemoullec, U. Pettersson, and M. Perricaudet. 1984. mRNAs from human adenovirus 2 early region 4 . J. Virol. 51: 822-831.

Weinberg, D.H. and G. Ketner. 1983. A cell line that supports the growth of a defective early region 4 deletion mutant of human adenovirus type 2. Proc. Natl. Acad. Sci. 80: 53835386.

Wu, C. 1985. An exonuclease protection assay reveals heatshock element and TATA box DNA-binding proteins in crude nuclear extracts. Nature 317: 84-87.

Yee, A.S., P. Raychaudhuri, L. Jokoi, and J.R. Nevins. 1987. Promoter interaction of E1A-inducible factor E2F and its potential role in the formation of a multicomponent complex. $E M B O$ I. 6: 2061-2068.

- 1989. The adenovirus-inducible factor E2F stimulates transcription after specific DNA-binding. Mol. Cell. Biol. 9: $578-585$.

Zajchowski, D.A., H. Bouf, and C. Kedinger. 1985. The adenovirus-2 early EIIa transcription unit possesses two overlapping promoters with different sequences requirements for E1A-dependent stimulation. EMBO J. 4: 1293-1300. 


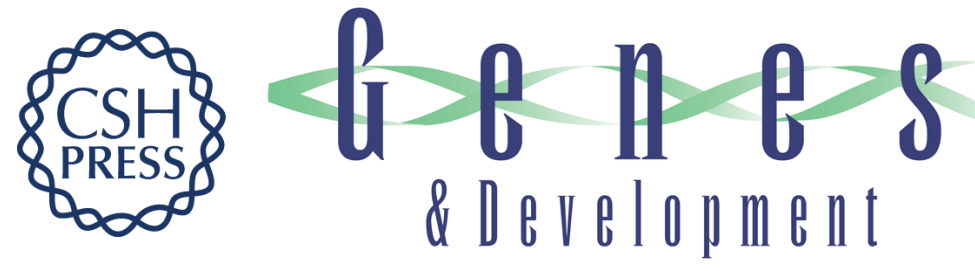

\section{The adenovirus early region 4 open reading frame $6 / 7$ protein regulates the DNA binding activity of the cellular transcription factor, $\mathrm{E} 2 \mathrm{~F}$, through a direct complex.}

$M$ M Huang and $P$ Hearing

Genes Dev. 1989, 3:

Access the most recent version at doi:10.1101/gad.3.11.1699

References This article cites 47 articles, 28 of which can be accessed free at:

http://genesdev.cshlp.org/content/3/11/1699.full.html\#ref-list-1

License

Email Alerting Receive free email alerts when new articles cite this article - sign up in the box at the top Service right corner of the article or click here.

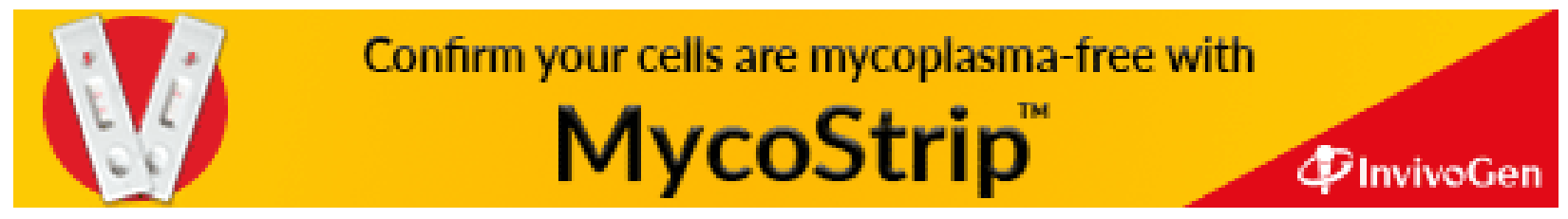

